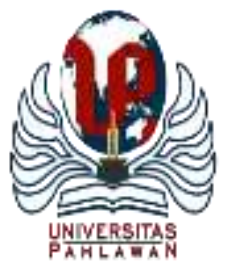

Edukatif : Jurnal Ilmu Pendidikan Volume 3 Nomor 6 Tahun 2021 Halm 4777 - 4785

EDUKATIF: JURNAL ILMU PENDIDIKAN

Research \& Learning in Education

https://edukatif.org/index.php/edukatif/index

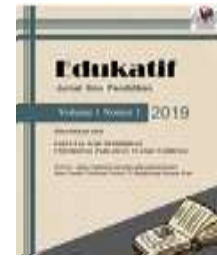

\title{
Familiarity of Online Learning Platform in Catching Up the Academic Accomplishment in East Kalimantan Sport School
}

\author{
Khusnul Khatimah ${ }^{1 凶}$, Yeni Rahmawati², Abdul Halim ${ }^{3}$ \\ Universitas Muhammadiyah Kalimantan Timur, Indonesia ${ }^{1,2,3}$ \\ E-mail : $\underline{\text { kk645@umkt.ac.id }}^{1}$, yr173@umkt.ac.id ${ }^{2},{\underline{\text { ah918@ } \text { umkt.ac.id }^{3}}}^{3}$
}

\begin{abstract}
Abstrak
Media pembelajaran semakin bervariasi seiring dengan pesatnya kemajuan teknologi. Metode tersebut banyak menggunakan berbagai media untuk meningkatkan kualitas hasil belajar. Objek penelitian ini adalah untuk mengidentifikasi pemanfaatan pembelajaran berbasis online untuk meningkatkan minat belajar siswa di kalangan siswa di Sekolah Olahraga Kalimantan Timur. Jumlah populasi penelitian ini adalah 423 siswa. Dengan menggunakan rumus Slovin diperoleh sebanyak 205 siswa. Metode pengumpulan data berupa kuesioner online sebagai instrumen penelitian. Kuesioner dikirimkan oleh peneliti dan meminta bantuan guru SKOI yang menjadi perantara juga. Untuk keperluan administrasi dalam proses pendataan dan pengolahan data, Dikarenakan kondisi pandemi COVID-19, beberapa siswa SKOI yang dipilih secara acak berada di luar kota sehingga pengisian angket berjalan lambat. Pada pertengahan tahun 2020 dilakukan pengolahan data. Dinyatakan bahwa data berdistribusi normal (data pre-test dan post-test). Dengan menggunakan uji Kolmogorov Smirnov dengan tingkat signifikansi .000 dengan tingkat uji korelasi sebesar .090 (menunjukkan bahwa data memiliki korelasi yang tinggi), data yang dimasukkan signifikan yaitu penggunaan Google suite untuk pembelajaran bahasa Inggris sangat baik. penting.
\end{abstract}

Kata Kunci: media, pembelajaran online, google suite, sekolah olahraga

\begin{abstract}
Learning media is increasingly varied along with the rapid technological advances. The method uses a lot of various media to improve the quality of learning outcomes. The object of this study was to identify the usage of online learning based to increase students' interest in learning among students in Sport School East Kalimantan. The total populations of this research were 423 students. By using Slovin formula, it was obtained as many as 205 students. The data collection method in the form was an online questionnaire as a research instrument. The questionnaire was sent by researchers and asked help from SKOI teachers who become intermediaries as well. For administrative purposes in the process of data collection and data processing, Due to the COVID-19 pandemic conditions, some SKOI students who were randomly selected were out of town causing the filling of the questionnaire to run slowly. In the middle of 2020, data processing was carried out. It was stated that the data were normally distributed (pre-test and post-test data). By using the Kolmogorov Smirnov test with a significant level of .000 with a correlation test level of .090 (indicating that the data has a high correlation), the data entered was significant, namely that the use of the Google suite for learning English was very significant.
\end{abstract}

Keywords: media, online learning, google suite, sport school

Copyright (c) 2021 Khusnul Khatimah, Yeni Rahmawati, Abdul Halim

$\triangle$ Corresponding author:

Email : kk645@umkt.ac.id $\quad$ ISSN 2656-8063 (Media Cetak)

DOI : https://doi.org/10.31004/edukatif.v3i6.1290 ISSN 2656-8071 (Media Online)

Edukatif : Jurnal Ilmu Pendidikan Vol 3 No 6 Tahun 2021 p-ISSN 2656-8063 e-ISSN 2656-8071 
4778 Familiarity of Online Learning Platform in Catching Up the Academic Accomplishment in East Kalimantan Sport School - Khusnul Khatimah, Yeni Rahmawati, Abdul Halim

DOI: https://doi.org/10.31004/edukatif.v3i6.1290

\section{INTRODUCTION}

As the COVID-19 pandemic is still growing, the Indonesian government issued the Presidential Decree No.7 of 13 March 2020, the Government Regulation No. 21 of 31 March 2020, Decree No.9 of 3 April 2020, and the Presidential Decree No. 12 of 13 April 2020. In addition, at the level of higher education, the DirectorGeneral of Higher Education issued about Learning Activity during Emergency Period of COVID-19 Pandemic which was to bolster the issued regulation mainly on Social Distancing on a Large Scale (PSBB) so the learning activities can be carried out from home in online or offline mode. However, following the condition of COVID-19 spread, Indonesian MOEC supported the online learning to be held mainly in the areas affected by COVID-19 because it promotes physical distancing and reduces virus spread (Wajdi, M. B. N., Kuswandi, I., Faruq, U. Al, Zulhijra, Khairudin, 2020). Yet, in the implementation of online learning, the point of "adjust[ing] distance learning practices according to the conditions of specific regions" should be taken seriously into consideration (Azzahra, 2020). However, the excitement for blending new technologies into the teaching-learning process has been compromised by a lack of suitable conceptual frameworks on the one hand (Neumeier, 2005), and, more importantly, the poor adoption of such tools by language teachers (Bush, 2008; Garrett, 2009) on the other.

Concerning online learning implementation in English classroom context, many projects have been reported. Particularly, the significance of technology was also found in K-12 classroom, (Thieman, 2008) reported that most pre-service teachers implemented their technology skills for supporting instructional practices in K-12 classroom. However, in their studies of technology integration through online teaching, (Arkorful, V., \& Abaidoo, 2014; Chawinga, 2017) discovered some benefits and drawbacks. Further, (Pilli, 2015) reported the use of social media as a powerful tool in educational aspects. Similarly, (Bal, E., \& Bicen, 2018) revealed that the university students perceived that social media was effective in promoting information acquisition and increasing their motivation by getting involved in supporting groups and the environment. (Beemt, A. V. D., Thurlings, M., \& Willems, 2020) reviewed articles and found that the research on social media use for the educational setting has been widely conducted but the studies of interrelatedness among the aspects such as students, teachers, and school in the implementation of social media still need further research.

In the Indonesian EFL setting, several studies have been conducted related to online learning. To mention some, (Atmojo, A. E. P., \& Nugroho, 2020; Bali, S., \& Liu, 2018; Basri, M., \& Paramma, 2019; Cakrawati, 2017; Mudra, 2018; Rachman, D., Sunarti, 2019; Tigowati, Efendi, A., \& Budiyanto, 2017), may represent the trend. Focusing on the implementation of e-learning platforms in English teaching context, (Tigowati, Efendi, A., \& Budiyanto, 2017) found that students' cognitive performance was higher after they were taught by using Schoology. By the same token, (Rachman, D., Sunarti, 2019) study revealed that Schoology also contributed to the improvement of students' English learning outcomes at the Nursing Program. Then, some researchers emphasized the students' perception. (Cakrawati, 2017) the study is on students' perception towards the use of Edmodo or Quipper. (Mudra, 2018) investigated students' perception in terms of perception and attitudes of Blended Learning, negative impression of Blended Learning and the concept of Blended Learning whereas (Basri, M., \& Paramma, 2019) researched students' perception by utilizing the modified Acceptance Model. In addition, (Bali, S., \& Liu, 2018) explored students' perception towards face-to-face (F2F) and online learning by taking three factors i.e. social presence, social interaction, and satisfaction into consideration. Then, the current study of online learning implementation was undertaken by focusing on EFL teachers' reflections towards the online teaching they have done in the COVID-19 pandemic (Atmojo \& Nugroho, 2020). In the Iranian context, some studies have investigated the EFL teachers' perceptions and use of online technologies in the classroom as well (Atai, M. R., \& Dashtestani, 2013; Dashtestani, R., \& Sharifi, 2012; Dashtestani, 2012; Golchinpour, 2013) 
4779 Familiarity of Online Learning Platform in Catching Up the Academic Accomplishment in East Kalimantan Sport School - Khusnul Khatimah, Yeni Rahmawati, Abdul Halim

DOI: https://doi.org/10.31004/edukatif.v3i6.1290

This is in line with the situation of Covid-19 and students at the Sekolah Khusus Olahragawan Internasional (SKOI) in East Kalimantan, whereby various learning models require teachers to make innovative and creative learning innovations to accommodate student learning methods in SKOI. This is because the students who overall are athletes have to divide their time among three important things namely: class schedules, training schedules, and match schedules. It is not uncommon for students to sacrifice their schedule as if to participate in training and competitions. This situation forces teachers to find learning strategies that can improve student learning outcomes who also work as athletes so that students can continue their profession without sacrificing their education.

\section{METHODOLOGY}

\section{Population and Sample}

Respondents in this research were students from overall levels under East Kalimantan International Sports School (SKOI Kalimantan Timur) with a total population of this research were 423 students. By using the Slovin formula, it was obtained as many as 205 students (margin error $=5 \%$ ) who randomly became a volunteer as respondents.

\section{Instruments}

The data collection method in the form was an online questionnaire as a research instrument. The questionnaire was sent by researchers and asked help from SKOI teachers who become intermediaries as well. For administrative purposes in the process of data collection and data processing, Due to the COVID-19 pandemic conditions, some SKOI students who were randomly selected were out of town causing the filling of the questionnaire to run slowly. In the middle of 2020, data processing was carried out.

\section{Data Analysis Procedures}

Several statistical counting were treated and one of them was descriptive statistical analysis. This research method was quantitative by using a pretest-posttest one-group experimental design to increase student motivation in learning English which is given in general Basic English (Daily vocabulary and expression) for overall SKOI students from elementary to high school education level.

\section{FINDINGS AND DISCUSSION}

From the results of descriptive data, it shows that the largest gender of SKOI students who have taken the test (pre-test) was dominated by male students with a total of $72.68 \%$. Most of the education levels come from high school (62.92\%). Most of them claimed that it was easy to access the internet $(75.61 \%)$ and around $4.88 \%$ summed that it was difficult to access the internet from their location. Moreover, the homestay between in the city and outside the city was balanced. Most of the participants admitted that they were familiar with the understanding of the use of the digital service "Google". Furthermore, the most surprising and impressive was that even though they already claim to be familiar with this type of digital service application or platform, they admitted that they don't know the term Google Classroom. This was admitted by half of the participants (50.24\%). Meanwhile, the access time of each participant has the highest average at the moderate level, namely 2-4 hours (55.61\%). The following table presentation of data collection results and processing in terms of descriptions taken from the questionnaire instrument when the pre-test was first performed. At this time there was no PSBB (Large-Scale Social Restrictions) but a transition period had already begun, even though in educational institutions/schools and public agencies WFH (Work from Home) or BDR (Learning from Home) had not been carried out. 
4780 Familiarity of Online Learning Platform in Catching Up the Academic Accomplishment in East Kalimantan Sport School - Khusnul Khatimah, Yeni Rahmawati, Abdul Halim

DOI: https://doi.org/10.31004/edukatif.v3i6.1290

Table 1

Respondent Demographic

\begin{tabular}{|c|c|c|c|}
\hline Item & Criteria & Number & $\%$ \\
\hline \multirow{2}{*}{ Gender } & Boy & 149 & 72.68 \\
\hline & Girl & 56 & 27.32 \\
\hline \multirow{3}{*}{ Education Level } & Elementary School & 0 & 0 \\
\hline & Junior high school & 76 & 37.07 \\
\hline & Senior high school & 89 & 62.92 \\
\hline \multirow{3}{*}{ Internet Access } & Easy & 155 & 75.61 \\
\hline & Medium & 40 & 19.51 \\
\hline & Hard & 10 & 4.88 \\
\hline \multirow{2}{*}{ Home stay } & City & 110 & 53.66 \\
\hline & Out of the city & 95 & 46.34 \\
\hline \multirow{3}{*}{$\begin{array}{l}\text { Google comprehending as } \\
\text { a digital service platform }\end{array}$} & Easy & 76 & 37.07 \\
\hline & Medium & 89 & 43.41 \\
\hline & Hard & 40 & 19.51 \\
\hline \multirow{3}{*}{ Google Classroom usage } & Familiar & 54 & 26.34 \\
\hline & Medium & 48 & 23.41 \\
\hline & Unfamiliar & 103 & 50.24 \\
\hline \multirow{3}{*}{ Google access per day } & $1-2$ hours & 37 & 18.05 \\
\hline & 2-4 hours & 114 & 55.61 \\
\hline & $>4$ hours & 54 & 26.34 \\
\hline Total & & 205 & 100.00 \\
\hline
\end{tabular}

This research method was quantitative by using a pretest-posttest one-group experimental design to increase student motivation in learning English which is given in general Basic English (Daily vocabulary and expression) for overall SKOI students from elementary to high school education level.

Table 2

\begin{tabular}{ccc}
\multicolumn{3}{c}{ Research Design } \\
\hline O1 & $\mathrm{X}$ & $\mathrm{O} 2$ \\
\hline Pretest & Treatment & Posttest \\
\hline
\end{tabular}

The time applied for the experiment was from March 2020 to May 2020. The randomly selected students were initially formed by a group in the WhatsApp media (due to the Pandemic) then given a questionnaire to fill in the data about their identity, the demographic results of which were listed in the table above (table 1). Students were then given a pre-test on questions in general and in easy categories in English levels such as greetings, greetings, pronouns, and daily used activities. Questions are given online through Google Forms which were integrated into Google Classroom. Since several students revealed that they didn't familiar yet with this part of the google Suit Application specifically in Google Classroom (GC) then the students were given a short tutorial (video) related to this platform system. After the pre-test results are collected, students are given treatment several times from March to May 2020 (a total of 14 scheduled meetings were announced via the WhatsApps (WA) chat group including the pre-test and post-test sessions) at the last meeting, a post-test was held.

The pre-test was held in March, 50 multiple choice questions from options A to D were given regarding greetings, pronouns, and vocabulary in English used in everyday life. From the results of this pre-test, a data score diagram shows that the lowest score of 205 participants was 30 and the highest score was 70 with an average score of 54. Meanwhile, the most frequent scores for participants were 60 with a mean score of 56. Below is an illustration that shows the results of the participants' scores along with the table descriptions during the pre-test. 
4781 Familiarity of Online Learning Platform in Catching Up the Academic Accomplishment in East Kalimantan Sport School - Khusnul Khatimah, Yeni Rahmawati, Abdul Halim

DOI: https://doi.org/10.31004/edukatif.v3i6.1290

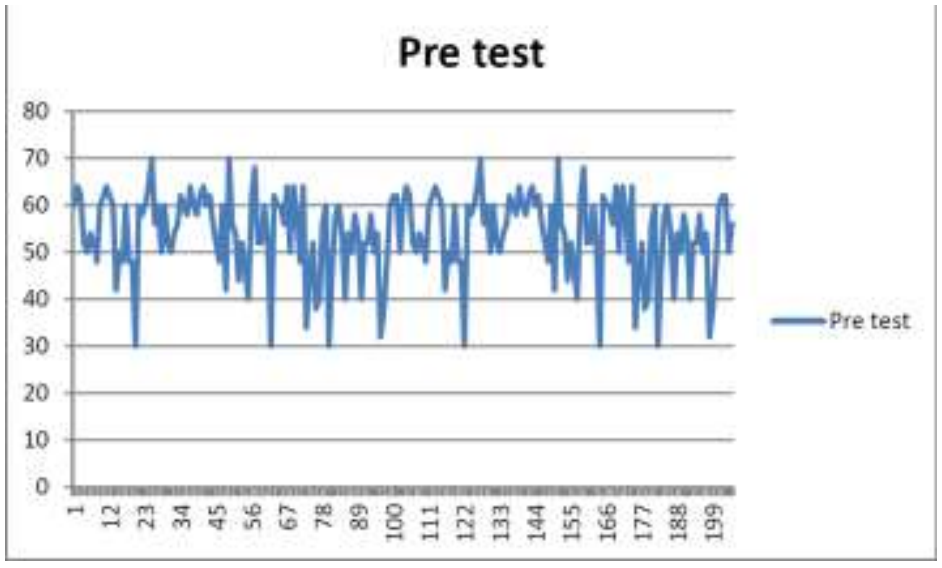

Figure 1. Pre-Test Line Diagram

The following table is the result of pre-test data. It was analyzed by using descriptive statistics. From the table below, it is explained that the mean score of the pre-test reached 53.99 ( $\mathrm{SD}=8.77)$. It means that the result pre-test was categorized low from a total number of respondents 205. Most of the students got a score around $60($ Mode $=60)$ with a minimum score of 30 and the maximum score was 70.

Table 3

Result of Descriptive Statistic for Pre-test

Column 1

\begin{tabular}{lc}
\hline Mean & 53.9902439 \\
\hline Standard Error & 0.612557505 \\
\hline Median & 56 \\
\hline Mode & 60 \\
\hline Standard Deviation & 8.770488754 \\
\hline Sample Variance & 76.92147298 \\
\hline Kurtosis & 0.475232061 \\
\hline Skewness & -0.861708128 \\
\hline Range & 40 \\
\hline Minimum & 30 \\
\hline Maximum & 70 \\
\hline Sum & 11068 \\
\hline Count & 205 \\
\hline Largest (1) & 70 \\
\hline Smallest (1) & 30 \\
\hline Confidence Level (95.0\%) & 1.207755676 \\
\hline
\end{tabular}

As mentioned earlier, the pre-test was held by using several themes such as introduction and greeting theme, compliment theme, direction theme, number and time theme, and family theme. In another word, there are five themes given. From the pre-test results, it was found that some participants were able to answer questions in English as a whole during the pre-test in terms of greeting and introduction theme was 20.29\%, while participants who answered correctly about multiple choice questions in the form of compliment theme were $19.06 \%$, the capability of respondent answering the questions in English direction theme was 20.67\%. Whereas, the Number and time theme was merely reached $18.54 \%$ of respondents who succeed to answer the question. Moreover, material related to the family theme was successfully answered by $15.71 \%$ of respondents. The following shows a bar chart regarding the percentage of participants' ability to answer multiple-choice questions during the pre-test session (figure 2). 
4782 Familiarity of Online Learning Platform in Catching Up the Academic Accomplishment in East Kalimantan Sport School - Khusnul Khatimah, Yeni Rahmawati, Abdul Halim

DOI: https://doi.org/10.31004/edukatif.v3i6.1290

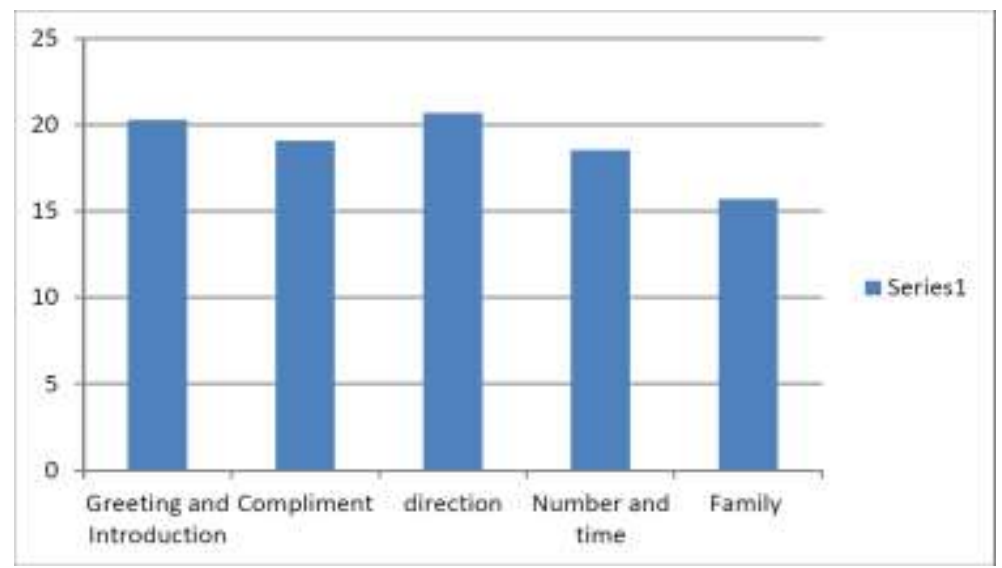

Figure 2. Pre-test Theme and result

The total number of meetings in the experiment (one group pre-test post-test design, see table 1) had 14 meetings including the pre-test and post-test (total treatment 12 times). Because at the time of the collection of this data it coincided with the first transition to the implementation of WFH (Work from Home) and the term learning from home (BDR), several of the participants returned to their hometown (not occupying in SKOI dormitory) during the pre-test, application of treatment as well as when the post-test was held. However, when the first data was collected, participants had a chat group created via WhatsApp application. The researcher still can monitor and have an active discussion while they did WFH/BDR. Therefore, the problem such as conventional meeting could be overcome by means of online communication via Group Chat. The provision of material was also through several supporting applications from Google such as YouTube (YouTube views 4 times with a duration of under 5 minutes including tutorials on using Google Classroom (> 5 minutes)), 3 meetings/treatments using the Google Meet application (to maximize meetings and for savings internet quota fee, then the session on Google Meet took less than 60 minutes). The provision of material was also via the internet which is integrated with Google (2 times) and 3 meetings with guidance through group chat. The material was given and delivered as simply as possible, thus, those participants who are at various levels can follow it.

Absence was done during online meetings as well. Even though there were obstacles, they could be implemented in the end. The following were the results of participants' attendance percentage in online learning/online treatment. By going through online absences, as many as $73 \%$ of participants could take the treatment, while $14 \%$ said they were sick and $13 \%$ had no more information. The figure below depicts the percentage of attendance.

\section{Total of Attendance Percentage}

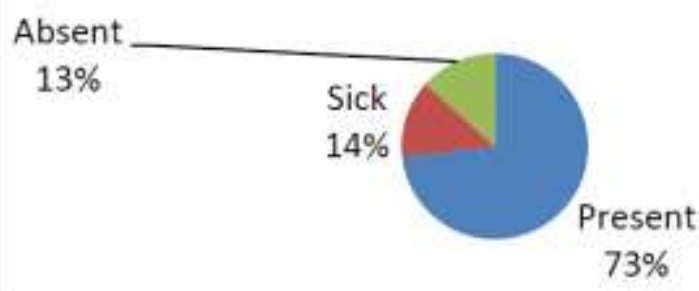

Figure 3. Attendance Percentage

The content of the material in the treatment that took place consisted of several themes, namely 3 meetings to discuss greeting material, 2 meetings to discuss compliment, the material for direction had a 
4783 Familiarity of Online Learning Platform in Catching Up the Academic Accomplishment in East Kalimantan Sport School - Khusnul Khatimah, Yeni Rahmawati, Abdul Halim

DOI: https://doi.org/10.31004/edukatif.v3i6.1290

duration of 3 meetings, 2 meetings for number and time theme, and 2 for family meetings. The material was provided online with several applications under Google platform, it was uploaded through Google classroom. In addition, to remind students, information was also provided on the WhatsApps group about the material that has been uploaded to the GC (Google Classroom) for each meeting. The duration of learning was carried out was counted for 90 minutes per meeting. The following diagram (figure 4) are the results of the post-test scores after 12 meetings were held.

Post Test

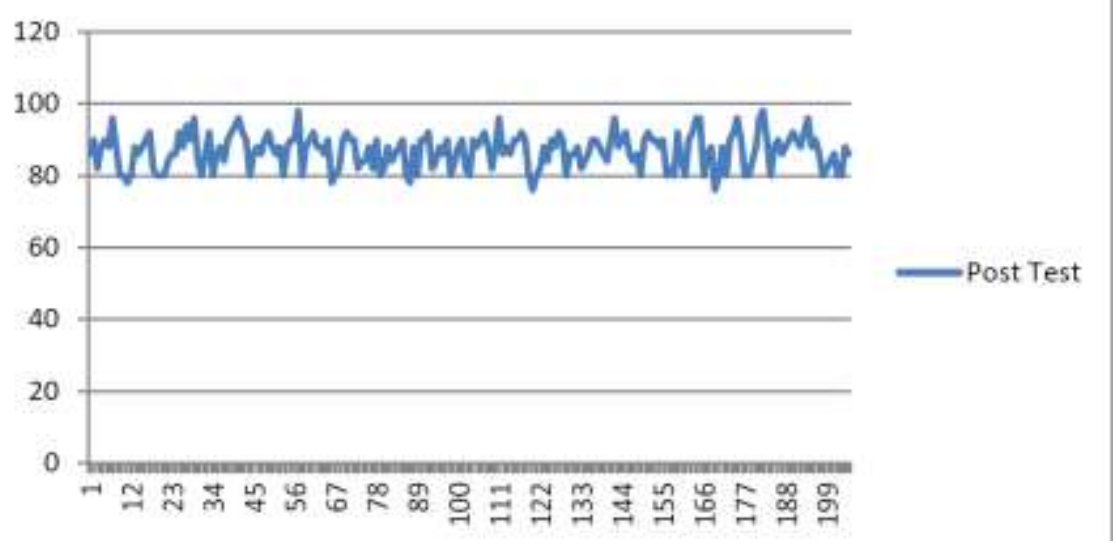

Figure 4. Result of Posttest

The diagram above shows that the range of scores during the post-test has increased from the lowest score of 76 and the highest score to 98. With a mean score of $86.86(\mathrm{SD}=4.76)$. Meanwhile, the value that often appears is 90 with a mean value of 88 . The majority of students got a score of 90 with a median was 88 . Although some of the students somehow didn't follow the instruction during the treatment (check figure 3 which explained $13 \%$ of respondents didn't confirm their situation), however, they participated in the final test/post-test. The researchers asked the active participants to handle the other respondents who were lost contact with the researcher.

Table 4

The Descriptive Result of Post-Test

\begin{tabular}{ll}
\hline & Column1 \\
\hline Mean & 86.86829268 \\
\hline Standard Error & 0.332858721 \\
\hline Median & 88 \\
\hline Mode & 90 \\
\hline Standard Deviation & 4.76581161 \\
\hline Sample Variance & 22.71296031 \\
\hline Kurtosis & -0.588175107 \\
\hline Skewness & -0.099683889 \\
\hline Range & 22 \\
\hline Minimum & 76 \\
\hline Maximum & 98 \\
\hline Sum & 17808 \\
\hline Count & 205 \\
\hline Largest(1) & 98 \\
\hline Smallest(1) & 76 \\
\hline Confidence Level(95.0\%) & 0.656284522 \\
\hline
\end{tabular}

Based on the test using SPSS, it was stated that the data were normally distributed (pre-test and post-test data). Furthermore, with the Kolmogorov Smirnov test with a significant level of .000 with a correlation test 
4784 Familiarity of Online Learning Platform in Catching Up the Academic Accomplishment in East Kalimantan Sport School - Khusnul Khatimah, Yeni Rahmawati, Abdul Halim

DOI: https://doi.org/10.31004/edukatif.v3i6.1290

level of .090 (indicating that the data has a high correlation), the data entered was significant so that it can be concluded that $\mathrm{H} 0$ was rejected and Ha was accepted, namely that the use of the Google suite for learning English was very significant.

Meanwhile, in terms of the motivation questionnaire given online, it also experienced a significant positive increase even though with a moderate level of correlation. The data which have been analyzed was normally distributed (.000). According to the motivation questionnaire that was distributed there was a similarity during the post-test and pretest students experienced increase in learning using services in the Google suite, namely Google classroom. They feel use Google classroom was very efficient and flexible moreover it can be used to collect assignments via smart phone.

\section{CONCLUSION}

The results of this study actually have many benefits and influences not only in the IT field, especially for the owner of this application, but also greatly influence and play a major role in the field of education. Because this application is very beneficial for most students and also for educators, especially educators who are also beginners using this application. Based on the data obtained from this study, it can be concluded that the Google Suite application is easy, so this application can be a platform option that can be used in online learning.

\section{REFERENCES}

Arkorful, V., \& Abaidoo, N. (2014). The role of e-learning, the advantages and disadvantages of its adoption in Higher Education. International Journal of Education and Research, 2(12), 397-410.

Atai, M. R., \& Dashtestani, R. (2013). Iranian English for academic purposes (EAP) stakeholders' attitudes toward using the Internet in EAP courses for civil engineering students: promises and challenges. Computer Assisted Language Learning, 26(1), 21-38. https://doi.org/DOI:10.1080/09588221.2011.627872

Atmojo, A. E. P., \& Nugroho, A. (2020). EFL classes must go online! Teaching activities and challenges during COVID-19 pandemic in Indonesia. Register Journal, 13(1), 49-76.

Azzahra, N. F. (2020). Addressing distance learning barriers in Indonesia amid the Covid-19 pandemic. Policy Brief, 2(1-8).

Bal, E., \& Bicen, H. (2018). The purpose of students' social media use and determining their perspectives on education. Procedia Computer Science, 177-181. https://doi.org/ttps://doi.org/10.1016/j.procs.2017.11.226

Bali, S., \& Liu, M. C. (2018). Students' perceptions toward online learning and face-to-face learning courses. Journal of Physics: Conference Series, 1-7. https://doi.org/https://doi.org/10.1088/1742-6596/1108/1/012094

Basri, M., \& Paramma, M. A. (2019). EFL students' perspective on the usefulness of ICT based learning in Indonesian higher education. ELT Worldwide: Journal of English Language Teaching, 6(2), 104-120. https://doi.org/https://doi.org/10.26858/eltww.v6i2.10515

Beemt, A. V. D., Thurlings, M., \& Willems, M. (2020). Towards an understanding of social media use in the classroom : a literature review. Technology, Pedagogy and Education, 29(1), 35-55.

Bush, M. D. (2008). Computer-assisted language learning: From vision to reality? CALICO Journal, 25(3), 443-470.

Cakrawati, L. M. (2017). Students ' perceptions on the use of online learning platforms in EFL classroom. English Language Teaching and Technology Journal, 1(1), 22-30.

Chawinga, W. D. (2017). Taking social media to a university classroom : Teaching and learning using Twitter 
4785 Familiarity of Online Learning Platform in Catching Up the Academic Accomplishment in East Kalimantan Sport School - Khusnul Khatimah, Yeni Rahmawati, Abdul Halim

DOI: https://doi.org/10.31004/edukatif.v3i6.1290

and blogs. International Journal of Educational Technology in Higher Education, 14(3), 1-19. https://doi.org/https://doi.org/10.1186/s41239-017-0041-6

Dashtestani, R., \& Sharifi, A. (2012). Web-based assessment of academic vocabulary: Iranian EAP students ' attitudes, confidence and self-efficacy.

Dashtestani, R. (2012). Barriers to the implementation of CALL in EFL courses: Iranian EFL teachers' attitudes and perspectives. The JALT CALL Journal, 8(2), 55-70.

Garrett, N. (2009). Computer-assisted language learning trends and issues revisited: Integrating innovation. The Modern Language Journal, 93 (focus, 719-740.

Golchinpour, R. (2013). ICT use in high school EFL instruction: Teachers' perceptions and practices. Azad University.

Mudra, H. (2018). Blended English language learning as a course in an Indonesian Context: An exploration toward EFL learners' perceptions. Journal of Foreign Language Education and Technology, 3(2), 28 51.

Neumeier, P. (2005). A closer look at blended learning--parameters for designing a blended learning environment for language teaching and learning. ReCALL, 17(2), 163-178.

Pilli, O. (2015). The changes in social media usage: Students' perspective. Anthropologist, 22(2), 345-354. https://doi.org/https://doi.org/10.1080/09720073.2015.11891886

Rachman, D., Sunarti, \& A. (2019). The effect of e-learning based schoology on the learning outcomes in nursing program. Indonesian Journal of Language Teaching and Linguistics, 4(3), 163-172. https://doi.org/https://doi.org/10.30957/ijotl-tl.v4i3.607.

Thieman, G. Y. (2008). Using technology as a tool for learning and developing 21st century citizenship skills : An examination of the NETS and technology use by preservice teachers with their K-12 students. Contemporary Issues in Technology and Teacher Education, 8(4), 342-366. https://citejournal.org/wpcontent/uploads/2016/04/v8i4socialstudies1.pdf

Tigowati, Efendi, A., \& Budiyanto, C. (2017). Indonesian journal of informatics education the influence of the use of e-learning to student cognitive performance and motivation in digital simulation course. Indonesian Journal of Informatics Education, 1(2), 41-48. https://doi.org/https://doi.org/10.20961/ijie.v1i2.12812

Wajdi, M. B. N., Kuswandi, I., Faruq, U. Al, Zulhijra, Khairudin, \& K. (2020). Education policy overcome coronavirus: A study of Indonesians. (pp. 96-106). Edutec: Journal of Education and Technology. https://doi.org/https://doi.org/10.29062/edu.v3i2.42 